\title{
Translation of Repetitions in Text: A Systemic Functional Approach
}

\author{
Qingshun $\mathrm{He}^{1}$ \\ ${ }^{1}$ Faculty of English Language and Culture, Guangdong University of Foreign Studies, Guangzhou, China \\ Correspondence: Faculty of English Language and Culture, Guangdong University of Foreign Studies, \\ Guangzhou, China. Tel: 86-158-0002-9026. E-mail: markman1998@163.com
}

Received: June 20, 2014 Accepted: July 21, 2014 Online Published: October 1, 2014

doi:10.5539/ijel.v4n5p81 URL: http://dx.doi.org/10.5539/ijel.v4n5p81

\begin{abstract}
Repetition in the Hallidayan sense functions as a cohesive device; it plays an important part in the construction of text. Repetition occurs at different levels of language and the translation of repetitions in text helps fulfill the criterion of equivalence of translation. According to the translation process, this paper puts forwards the translation criterion of unmarked equivalence and then discusses the translation of repetitions from the language levels of phonology, lexis and syntax, and the treatment of redundancies, pointing out that appropriate treatment of repetitions in translation is a prerequisite to follow the translation criterion of unmarked equivalence.
\end{abstract}

Key words: repetition, systemic functional linguistics, translation criterion, unmarked equivalence

\section{Introduction}

Of the three metafunctions (ideational, interpersonal and textual) of Systemic Functional Linguistics (Halliday, 1985; 1994; Halliday \& Matthiessen, 2004; 2014), textual metafunction is a "relevant" function, or namely, "the integrity, consistency and cohesiveness" (Hu et al., 1989, p. 135). The textual metafunction consists of three systems, i.e., the thematic system, the information system and the cohesion system. "The concept of cohesion is a semantic one" (Halliday \& Hasan, 1976, p. 4), it refers to "the way certain words or grammatical features of a sentence can connect that sentence to its predecessors (and successors) in a text" (Hoey, 1991, p. 3). Cohesion arises when the interpretation of one language element depends on that of another. In discussing the cohesive patterns in English, Halliday \& Hasan (1976) divide cohesion into grammatical cohesion and lexical cohesion. The former consists of reference, substitution, ellipsis and conjunction, and the latter, reiteration (repetition, synonymy, antonymy, hyponymy, meronymy and general nouns, etc) and collocation (co-occurrence of lexical items). They define reiteration as a form of lexical cohesion which involves "the repetition of a lexical item, or the occurrence of a synonym of some kind, in the context of reference; that is, where the two occurrences have the same referent" (Halliday \& Hasan, 1976, pp. 318-319). Hoey (1991) develops the repetition in the Hallidayan sense into simple repetition, complex repetition, simple paraphrase, complex paraphrase, superordinate, hyponymy, co-reference, substitution and ellipsis, etc. Hu (1994) further includes phonological repetition into the cohesion system because language is itself multi-stratal.

Based on relevant theories on repetition as a cohesive device, this research intends to discuss the translation of repetitions in text. For this purpose, we will first offer a sketch of repetition in text in Section 2. In Section 3, we will discuss the process of translation and put forward the concept of unmarked translation. Finally, in Section 4, we will analyze the translation of repetition from such language levels as phonology, lexis and syntax, and the treatment of information repetition in non-literary works.

\section{Repetitions in Text}

Repetitions in text can be classified into phonological repetition, lexical repetition and syntactic repetition.

\subsection{Phonological Repetition}

Phonological repetition is of non-negligible significance in the construction of text. It is widely used in poems to strengthen the beauty of rhythm and to make the poem more pleasing to the ear. For example:

(1) The breeze blew, the white foam flew

The furrow followed free;

We were the first that ever burst 
Into that silent sea.

(T. S. Coleridge: Rime of the Ancient Mariner)

\subsection{Lexical Repetition}

Lexical repetition in text is not structural but textual. It can appear in the same sentence, adjacent sentences or distant sentences. See example (2):

(2) There are more than 26000 patients on the national waiting list for transplants, an increase of 10000 patients over the last three years. More than 2000 patients are dying annually while waiting for transplants, mostly patients waiting for hearts, kidneys and livers. The shortage of organs is so acute that, last month, in an unprecedented procedure, surgeons at the University of Pittsburgh in Pennsylvania transplanted a baboon liver into a 35-year-old man dying of liver failure.

(Los Angeles Times 92.7.4)

In example (2), the following groups of words are directly repeated:

patients, patients, patients;

waiting, waiting, waiting;

transplants, transplants, transplanted;

dying, dying;

livers, liver, liver.

\subsection{Syntactic Repetition}

Syntactic repetition can be exemplified into parallelism and antithesis. Parallelism means the arrangement in a series (often three or more) of phrases or sentences similar in structure, closely relevant in meaning and consistent in mood. For example:

(3) I have a dream that one day this nation will rise up and live out the true meaning of its creed: We hold these truths to be self-evident; that all men are created equal. I have a dream that one day on the red hills of Georgia the sons of former slaves and the sons of former slave-owners will be able to sit down together at the table of brotherhood. I have a dream that one day even the state of Mississippi, a desert state sweltering with the heat of injustice and oppression, will be transformed into an oasis of freedom and justice.

(Martin Luther King Jr.: I Have a Dream)

Antithesis means to put in parallel two sentences or ideas similar in structure, equal in word number, relevant or opposite in meaning. For example:

(4) Penny wise, pound foolish.

(Addison: The Spectator)

\section{Towards an Unmarked Translation}

The method choice between literal translation and free translation has been disputed about since there were translation studies. The dispute between literal and free translation has evolved into that between the school of linguistics and that of arts nowadays. Many researchers attempt to find a way to make a compromise. For example, Barkhudarov (1975) established a theory of equivalent translation from the six language levels, i.e., phoneme (grapheme), morpheme, word, word group, sentence and discourse. It can be seen that it is a continuum from phoneme to discourse, and each of the levels represents a stage along this continuum. Therefore, literal translation and free translation are not opposite to each other; rather they should be complementary to each other along a continuum. The dispute between literal and free translation is in essence originated from the ambiguous identification of the two translation methods. According to Snell-Hornby (1995), the classifications of translation studies were too rigid with so many binary oppositions. This kind of pedantic binary oppositions is helpless for translation practice. The theory of prototype theory of translation proposed by Yang (2004) is actually a pursuit of a translation criterion of unmarked equivalence in the process of translation.

\subsection{Translation Process}

Nida \& Taber (1969) are the earliest translators studying the translation process. They believe that in the translation process, the source text should first be translated into an intermediate form which will then be translated into the target language. This intermediate form is referred to as the go-between language. According to Nida \& Taber (1969, p. 33), the translation process consists of three stages: analysis, transfer and restructuring. 
See Figure 1:

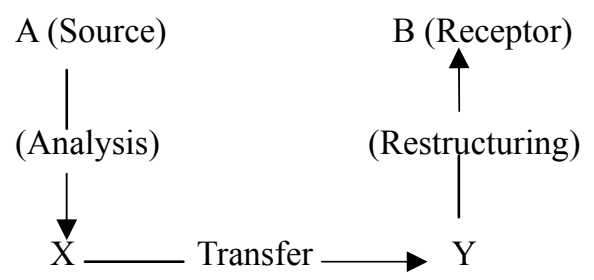

Figure 1. Translation Process by Nida \& Taber (1969)

Nina \& Taber (1969) develop their translating theory in the process of Bible translation. In the process of translation, understanding and analyzing play an important part. After understanding and analyzing, the translation enters into the transfer stage. The last stage is to restructure the translation to make it faithful to the source text to the maximum. Therefore, it is the translated text that is restructured, that is, restructuring is conducted following the stage of transfer. It is certain that this process also works when the mother language is translated into the foreign language. However, in the translation of some non-literary works, when the source text violates its own language standard, or when the information structure of the translated text is obviously marked, the restructuring of the source text is also necessary. Based on the understanding of the information of the source text, the translator comes to analyze the language structure of the source text and its textual characteristics, and then to restructure the information of the source text to facilitate translation. Therefore, in this process, the restructuring of the source text is also a dispensable stage. The translation process of Nida \& Taber (1969) can be revised as Figure 2:

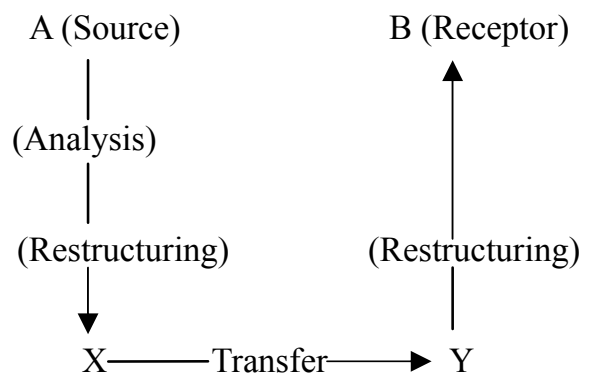

Figure 2. Revised translation process

\subsection{Unmarked Translation}

We here regard language as the signifier, and the conceptual meaning as the signified. Although there are significant differences between two languages, the conceptual meaning has its expression in each language. The author expresses the conceptual meaning (C) with the language of the source text (P1) in the environment of the source language (L1). The translated text (P2) is the representation of the same conceptual meaning (C) in the target language (L2). See Figure 3:

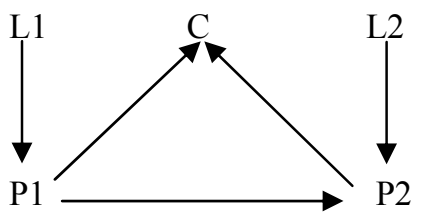

Figure 3. Relationship between the source and the target language in translation

$\mathrm{L} 1$ expresses $\mathrm{C}$ through $\mathrm{P} 1$, and $\mathrm{C}$ is expressed by $\mathrm{P} 2$ in $\mathrm{L} 2$. $\mathrm{P} 2$ acquires $\mathrm{C}$ from $\mathrm{P} 1$. Thus, not only will $\mathrm{P} 2$ express $\mathrm{C}$ which is expressed by $\mathrm{P} 1$, but also it will be constrained by $\mathrm{L} 2$. To express $\mathrm{C}$, the form of $\mathrm{P} 1$ remains in P2 without violating the constraint of L2. This is the traditional literal translation; to express $\mathrm{C}, \mathrm{P} 2$ takes the standard form of L2 with the form of P1 not followed. This is the so-called free translation. However, to keep the 
form of P1 with the constraint of L2 neglected will result in the so-called dead translation, and to break away the form of P1 to adopt the standard expression of L2 will result in the so-called wild translation. From dead translation to wild translation, it is the level translation proposed by Barkhudarov (1975). Both the wild translation giving up P1 and the dead translation giving up L2 are not preferable. Thus, literal translation and free translation are not the two poles in the binary opposition; rather they are at the different levels of the continuum. Since both literal and free translations emphasize that P2 expresses C through P1 and L2, the dispute between literal translation and free translation becomes meaningless. That literal translation emphasizes on P1 and free translation emphasizes on P2 shows exactly that literal translation and free translation are on the continuum. For example, the conceptual meaning of tree is expressed by different words in different languages.

When L1 expresses C through P1, P1 is the unmarked expression of L1, and now P2 is also the unmarked expression of L2. However, if $\mathrm{P} 1$ is the marked form of L1, P1 expresses not only the conceptual meaning $\mathrm{C}$ but also an additional meaning through the special language form. This requires P2 to express the special meaning expressed by P1 through a marked language form, which can be considered as the faithful translation in the true sense. Otherwise, it would be reduced to dead translation or wild translation. See example (5):

(5) a. I admire his learning, but I despise his character.

b. His learning I admire, but his character I despise.

The conceptual meaning expressed by the two sentences is the same, but they have different word order. (5a) is the normal structure, hence unmarked; the object of $(5 b)$ precedes the subject, so $(5 b)$ is structurally marked. The author expresses an additional meaning with this kind of marked structure, that is, "to emphasize the information of the object and to give prominence to the contrast between the two objects" (Wang, 1993, p. 36). Therefore, when translated into Chinese, the structural characteristics should be taken into consideration.

(6) a. 我佩服他的学识, 但鄙视他的人格。

b. 他的学识, 我佩服, 但他的人格, 我鄙视。

It can be seen from the above analysis that to achieve formal equivalence does not mean to literally copy the structure of the source text but to fully transfer the meaning of the source text with an appropriate structure of the translation.

The source text is the carrier of the source language, and its manifestation is constrained by the source language. The translation is the carrier of the target language, and its manifestation is constrained by both the source text and the translation. It is literal translation to translate the unmarked original text into the unmarked target language, or the marked original text into marked target language, with the original meaning remaining in the translation process. Here the form and meaning are different from those in the traditional sense. The formal equivalence here means that the relationship between the translated text and the target language is equivalent with that between the source text and the source language, while the meaning equivalence is still reflected in that between the translation and the original meaning. When the source text contains special cultural images and there are no corresponding cultural images in the target language, it is free translation to give up the cultural images for the accurate transfer of the original meaning. For example:

(7) It means killing two birds with one stone.

Translation 1. 这就意味着一石二鸟。

Translation 2. 这就意味着一箭双雕。

Translation 3. 这就意味着一举两得。

In (7), the two cultural images birds and stone in English have no relevant equivalents in Chinese, so it can be translated as translation 1. However, there is an idiom in Chinese 一箭双雕 equivalent to the English two birds with one stone, thus it can also be translated as translation 2. Translations 1 and 2 are correspondent in both form and meaning, and hence are faithful translations. As for the different cultural images, this is because they adopt the translation strategies of foreignization and domestication respectively. There are no changes in translation method. If it is translated as translation 3, although the original meaning is also transferred, the cultural images have lost, hence is not successful translation.

It can be seen that the cultural images in the source text can be substituted for by the equivalent cultural images in the target language with the translation strategy of domestication, or be maintained with the translation strategy of foreignization. If the original cultural image has special cultural implications, it can be retained with appropriate explanation. 


\section{Translation of Repetitions}

In this section, we will discuss the translation of phonological, lexical and syntactic repetitions and that of the unnecessary repetition in non-literary text.

\subsection{Translation of Phonological Repetition}

Phonological repetition can enhance the rhythm of language, and it is popularly used in poetry. In poetry translation, not only should the meaning be expressed, but also the rhyme of the original poem should be reproduced through appropriate treatment of phonological repetitions, so that the readers of the translated text can have the same feeling as those of the source text. Here is an example:

(8) O my Luve's like a red red rose

That's newly sprung in June;

O my Luve's like the melodie

That's sweetly played in tune.

(Robert Burns: A Red, Red Rose)

呵, 我的爱人像朵红红的玫瑰,

六月里迎风初开;

呵, 我的爱人像支甜甜的曲子,

奏得和谐又合拍。

(王佐良 译)

In this poem, June in the second sentence rhymes with tune in the fourth sentence, hence phonological repetition occurs. In the translation, 开/kai/ rhymes with 拍/pai/, so the rhyme of the original poem is reproduced in a flexible manner. When the meaning and form conflict, the translator often chooses to maintain the form and explain the meaning with endnotes. For example:

(9) 杨柳青青江水平, 闻郎江上踏歌声。

东边日出西边雨, 道是无晴却有晴。

(刘禹锡《竹枝词》)

The willows are green, green;

The river is serene;

There's his song wafted to me.

In the east the sun is rising;

In the west rain is falling;

Can you see if it's fair or foul?

Footnote: 晴/qíng/ here is a pun. On the one hand it means fairness of the weather, and on the other it implies 情 /qíng/, a homophone, which means love.

(translated by Zhang Qichun)

However, in the translation, although foul and fair are phonological repetition, which is faithful to the source text in form, the pun meaning contained in the source text has not been expressed. The translator solved this problem effectively with a footnote.

\subsection{Translation of Lexical Repetition}

Words and phrases are the basic unit of discourse. Lexical repetition is a major cohesive device (Halliday \& Hasan, 1976; Hoey, 1991). Due to the difference between Chinese and English, lexical repetition as a cohesive device is relatively more popularly used in Chinese than in English. However, repetition does not mean redundancy. Redundancy is to be avoided in both Chinese and English. Repetition should be avoided in English, but this does not mean that repetition is not allowed at all in English. Research shows that when the topic changes, lexical repetition is always used as a cohesive device in both Chinese and English (Yan \& Dong, 1999), 
but when the same topic continues, such grammatical devices as reference, substitution and ellipsis tend to be used in English and lexical repetition dominates in Chinese. For example:

(10) To spend too much time in studies is sloth; to use them too much for ornament, is affection; to make judgment wholly by their rules, is the humour of a scholar. They perfect nature, and are perfected by experience...

(Francis Bacon: Of Studies)

Translation 1. 把时间过多地花费在学问上, 是急惰; 把学问过多地用作装饰，是虚伪; 完全按学问 的规则来判断, 则是书呆子的嗜好。学问能使天性完美, 而经验又能使学问完善。(东 旭译 )

Translation 2. 读书太慢会驰惰, 为装㣴而读书是欺人, 只按照书本办事是呆子。求知可以改进人性, 而经验又可以改进知识本身。( 何新译 )

The cohesion chain of reference studies - them - their - They $-\Phi$ in the source text is translated into that of lexical repetition 学问 - 学问 _ 学问 _ 学问 _ 学问 in translation 1. However, in translation 2, they in the second sentence is translated as 求知 which becomes the starting point of the new information in text construction, the unmarked Theme in the source text is translated into a marked Theme, and the omitted they in the last sentence has been recovered as 知识, which is not the repetition of 求知, resulting in the non-coherence of the text. Therefore, translation 2 is equivalent to the source text in neither form nor meaning.

\subsection{Translation of Syntactic Repetition}

Syntactic repetition is also known as structural repetition. It is mainly used in such rhetorical devices as parallelism and antithesis, functioning to emphasize or to express specific meanings. In translation, such parallel structures should be maintained. In Of Studies, for example, there are 19 sentences, 13 of which contain parallel structures. This makes the text fluent, context clear and well-structured. In translation, the structure should be given full consideration for the equivalence in structure. See example (11):

(11) And therefore, if a man write little, he had need have a great memory; if he confer little, he had need have a present wit; and if he read little, he had need have much cunning, to seem to know that he doth not.

Translation 1. 因此, 如果一个人写得很少, 那末他就必须有很好的记性 ; 如果他很少与人会谈, 那 末他就必须有很敏捷的机智; 并且假如他读书读得很少的话，那末他就必须要有很大 的狡黠之才, 才可以强不知以为知。( 水天同译 )

Translation 2. 因此不常作笔记者须记忆力特强, 不常讨论者须天生㙂颖, 不常读书者须欺世有术, 始能无知而显有知。( 王佐良译)

Translation 1 is literal translation, striving to be faithful to the original in form. However, it is not necessary to translate the conjunction and which is popularly used in parallel structures in English as 并且 in Chinese. Moreover, since it is a parallel structure, the last 假如 might as well be translated into 如果. Translation 2 is free translation, but maintains the original syntactic repetition, making the translated text natural, refined, lively, faithful and fluent.

\subsection{Translation of Redundant Repetition}

Being faithful to the source text, i.e., the equivalence, is regarded as the highest standard of translation. Generally, any translation is required to truly reproduce the original meaning, with no increase or decrease. This standard is based on the primacy of the source text, especially the literary works. In the translation of such works, the translator should make the translation faithful to the source text not only in meaning but also in spirit, so the relevant forms of the source text should be retained in the translation. However, the translation of non-literary works focuses on the transfer of the basic information of the source text, that is, "to transfer the ideas, opinions, theories, fact and data contained in the source text to the readers of the translation" (Xie, 2003, p. 190). Language form is only the tool to convey information, so in the translation of such texts, the formal and standard language form is required for the accurate transfer of information. Because of the innate difference between the two languages, it is sometimes necessary to reduce the repeated information in non-literary translation. Here is an example:

(12) (1)吉林大学珠海学院地处中国最早对外开放的经济特区一珠海。(2)珠海在南海之滨, 珠江入 海口西岸, 东与香港隔海相望, 南与澳门陆地接连，世界瞩目的港珠澳大桥建成后，珠海到 澳门仅 3 分钟车程, 到香港只需 20 分钟车程, 珠江三角洲城际轻轨通车后珠海到广州和深圳 分别为 38 分钟。 
(3)校园位于珠海市金湾区草堂湾的观音山下、南海岸边，早晨“碧波托红日”，夜晚“海上 升明月”; 南面接珠海机场、航展中心和高栏港，北面近珠海火车站、京珠高速入口，具有海 陆空立体化交通、全方位物流优势。(4)校园依山傍海，风光绮丽，宁静宜人，空气清新，是 广大莘莘学子读书学习的理想家园。

(5)吉林大学珠海学院是吉林大学在我国改革开放前沿、经济高速发展、自然环境优越的 “珠三角”开设的战略窗口。

These sentences aim to introduce the superior geographical environment of the Zhuhai College of Jilin University. However, in the process of introduction, there appears a lot of repeated information, such as 中国最 早对外开放的经济特区 in (1) and 我国改革开放前沿，经济高速发展......的战略窗口 in (5), 校园位于...... 观音山下、南海岸边，早晨‘碧波托红日’, 夜晚“海上升明月’ in (3) and 校园依山傍海, 风光绮丽, 宁静宜 人, 空气清新 in (4), etc. Such repeated information is actually not acceptable in Chinese. According to Halliday \& Hasan (1976), the information structure of language follows the pattern of the Given information + the New information. A good text has appropriate amount of Given and New information. Too much Given information will make the text cumbersome and redundant, while too much New information will cause information overload, and the communication will be blocked (Zheng, 2002). Based on the above analysis, example (12) can be reorganized as (13):

(13) (1)吉林大学珠海学院地处中国最早对外开放的经济特区一一珠海。(2)珠海在南海之滨, 珠江入 海口西岸, 东与香港隔海相望, 南与澳门陆地接连, 世界瞩目的港珠澳大桥建成后，珠海到 澳门仅 3 分钟车程, 到香港只需 20 分钟车程, 珠江三角洲城际轻轨通车后珠海到广州和深圳 分别为 38 分钟。

(3)校园位于珠海市金湾区草堂湾的观音山下、南海岸边，南面接珠海机场、航展中心和 高栏港, 北面近珠海火车站、京珠高速入口, 交通非常便利。(4)校园风光绮丽, 宁静宜人, 空气清新, 是广大莘莘学子读书学习的理想家园。

(5)吉林大学珠海学院在“珠三角”地区具有重要的战略意义。

The reorganized version can be translated into English as:

Translation: The Zhuhai College of Jilin University is located in Zhuhai, one of the earliest Special Economic Zones in China. Zhuhai lies in the western part of the Pearl River Delta on the South China Sea, with Hong Kong situated to the east, and Macao to the south. It is a mere 3-minute drive from Zhuhai to Macao, and a 20-minute drive to Hong Kong. It is expected that the intercity light rail train of the Zhuhai Delta Region will take only 38 minutes to run from Zhuhai to Guangzhou and Shenzhen.

The campus is situated at the foot of Kwanyin Mountain on the edge of the South China Sea. It neighbours Zhuhai Airport and the Aerospace Exhibition Center, as well as the Gaolan Harbor to the south and the Zhuhai Railway Station and the entrance to the Beijing-Zhuhai Highway to the north, making it very convenient in terms of transportation. The campus, with its beautiful scenery, fresh air and serenity, is really an ideal place for students to study in.

The Zhuhai College of Jinlin University is of great strategic value in the Pearl River Delta Region.

\section{Conclusion}

Based on relevant theories on lexical repetition as cohesive devices, this research discussed the translation of repetitions in text from such language levels as phonology, lexis and syntax, and the treatment of the redundant information in non-literary works, pointing out that repetition plays an indispensible part in the construction of text, and the appropriate treatment of repetitions at different language levels is the prerequisite to achieve the standard of faithfulness of translation. However, because of the non-standard organization of the source text and the unclear information structure, it is necessary to reorganize the information structure and the language structure of the source text to reduce the repeated information before translation. This is to strive for the faithfulness to the information content of the source text but not to faithfully transfer the problems of the source text into the target text. 


\section{References}

Barkhudarov, L. C. (1975). Language and Translation. Moscow: International Relations Press.

Halliday, M. A. K. (1985). An Introduction to Functional Grammar. London: Edward Arnold.

Halliday, M. A. K. (1994). An Introduction to Functional Grammar (2nd ed.). London: Edward Arnold.

Halliday, M. A. K., \& Hasan, R. (1976). Cohesion in English. London: Longman Group.

Halliday, M. A. K., \& Matthiessen, C. M. I. M. (2004). An Introduction to Functional Grammar (3rd ed.). London: Edward Arnold.

Halliday, M. A. K., \& Matthiessen, C. M. I. M. (2014). Halliday's Introduction to Functional Grammar (4th ed.). London \& New York: Routledge.

Hoey, M. (1991). Patterns of Lexis in Text. Oxford: Oxford University Press.

Hu, Z. (1994). Discourse Cohesion and Coherence. Shanghai: Shanghai Foreign Language Education Press

Hu, Z., Zhu, Y., \& Zhang, D. (1989). A Survey of Systemic Functional Grammar. Changsha: Hunan Education Publishing House.

Nida, E. A., \& Taber, C. R. (1969). The Theory and Practice of Translation. Leiden: E. J. Brill.

Snell-Horby, M. (1995). Translation Studies: An Integrated Approach (revised). Amesterdam \& Philadelpha: John Benjamins

Wang, D, \& Zhang, Y. (1993). A comparison of English and Chinese word order and translation. Foreign Language Teaching and Research, 4, 36-44.

Xie, T. (2003). New Perspectives in Translation Studies. Qingdao: Qingdao Publishing House

Yan, S., \& Dong, H. (1999). A new perspective of textual coherence. Shandong Foreign Languages Journal, 3, $1-6$.

Yang, B. (2004). Towards the prototype theory of translation. Research in Foreign Language and Literature, 4, $106-111$.

Zheng, G. (2002). Chinese Text Linguistics. Beijing: Foreign Languages Press.

\section{Copyrights}

Copyright for this article is retained by the author(s), with first publication rights granted to the journal.

This is an open-access article distributed under the terms and conditions of the Creative Commons Attribution license (http://creativecommons.org/licenses/by/3.0/). 